\title{
CITIZENSHIP, SOVEREIGNTY AND GLOBALISATION: TEACHING INTERNATIONAL LAW IN THE POST-SOVIET ERA $†$
}

\author{
ANNE ORFORD*
}

\section{INTRODUCTION}

This article will deal with one aspect of feminist research and teaching about international law in the post-Soviet era: the need to think about international law ethically in ways that take account of how international lawyers are located in global networks of power. ${ }^{1}$ While international law has long been involved in "the organisation of power relations between white and 'other", ${ }^{2}$ it is particularly important in an era of global economic restructuring to study international law as a process that is implicated in the reproduction of inequality. ${ }^{3}$ As Andrea Rhodes-Little suggests:

For feminists ... the further challenge thrown down by "other" women is that of how to resist those social practices which produce inequality and divide women against each other within a global context as well as in local contexts. In short, feminists search for ethical practices which are answerable for the power relations they produce. We also search for law which acknowledges its position in the organisation of power relations between women and women and between white and "other". 4

My argument about the need for "ethical" practices of teaching and research about international law, practices "which are answerable for the power relations they produce", can be read as part of a larger debate about the need to reorient legal education and the production of knowledge about legality generally. ${ }^{5}$ It also draws on the work of those feminist and critical theorists who argue for the development of an ethical approach to education and to the production of knowledge in areas such as literary theory and cultural studies. ${ }^{6}$

The particular focus of this article is on the ways in which that approach to teaching international law can be explored through the inclusion, in international legal curricula, of material that questions the central notions of citizenship and sovereignty. In the first section, I will sketch some of the ways in which feminist theorists have attempted to ask a different set of questions about citizenship and sovereignty, by contesting the dominant conception of the citizen as a neutral disembodied individual, and by considering the implications of citizenship in a global context. Secondly, I will make some necessarily brief comments about teaching method, addressing the pedagogical issues that are raised when feminist, critical and postcolonial material is included in the law curriculum.

\section{FEMINIST APPROACHES TO CITIZENSHIP AND SOVEREIGNTY}

\section{Citizenship as a Discourse about Exclusion}

The denial of equal rights and full citizenship for women has long been a way of denying women's legal subjecthood in Western democracies. ${ }^{7}$ Accordingly, analysis of the ways in which the discourse of citizenship has been mobilised against the interests of women is of particular interest to feminist legal theorists, as well as political theorists and international relations scholars. ${ }^{8}$ Citizenship operates to exclude certain groups of people from rights, obligations and participation in the community. Indeed, citizenship can be characterised as a discourse that is fundamentally about exclusion. Many groups have suffered, and continue to suffer, as a consequence of being formally excluded from the benefits of being characterised as citizens. 
In a material sense, for example, many women within Australia, such as Aboriginal women, migrant women, refugees or the mentally ill, continue to occupy a shadowy land outside the full entitlements of citizenship. ${ }^{9}$ In terms of representational practices, women have also suffered through being represented as something Other to the neutral individual of liberal discourses of citizenship. ${ }^{10}$ Jan Pettman points to an "inside/outside borderland, where minorities, Aboriginal or ethnic, have an ambiguous nationality. Legally citizens, they are widely seen as not really belonging, marked by a difference that is potentially dangerous and somehow unpatriotic.”11

Feminists have also argued that the militarisation of citizenship means that women have been excluded from full status as citizens. ${ }^{12}$ The construction of women as incapable of engaging in "combat", itself an unstable category, means that women are perceived as incapable of defending the political body from attack. At best, women can hope to be the mothers of citizens when citizenship and militarised masculinity are linked in that way.

These feminist analyses have in common the recognition that citizenship functions as a way of shaping identity in Western culture. As Patricia Williams suggests, the concepts of rights and citizenship are the markers of our relation to others and our social and bodily boundaries. ${ }^{13}$ Accordingly the exclusion of many groups from citizenship in the liberal imagination continues to have serious implications for the status and security of the members of those groups.

\section{CITIZENSHIP, SOVEREIGNTY AND IDENTITY}

A second approach taken by feminists and other critical theorists has been to question the role that notions of citizenship and sovereignty play in our self-constitution as subjects. In late twentieth-century democracies, sovereignty serves as a "crucial modern myth of origin". ${ }^{4}$ The discourse of sovereign statehood operates to discipline differences both within and outside state borders by privileging presumed coherences within those borders. ${ }^{15}$ As Rob Walker argues:

(T)he state has provided the modern world's most powerful answer to all questions about who and what we are as political beings ... It asserts that we are, first and foremost, citizens. We are what we are within — subjects and subjectivities. And it is within us as much as we are within it. Only as citizens, it insists, can we become human. Only as citizens can we become secure, free, developed, democratic, peaceful. Privileging this answer has become the condition under which we can become anything else ... At least, this is the official story, and like all official stories it has a certain narrative advantage. ${ }^{16}$

The ways in which the myth of sovereignty operates to discipline differences within state borders has begun to receive the attention of feminist theorists in recent years. Many of us have questioned the notion of a disembodied abstract citizen operating in a harmonious public realm free of difference, and remain sceptical of the claim that we are, or ever were, first and foremost citizens. ${ }^{17}$ Instead, feminists have argued that both the sovereign and the citizen are embodied in the Western imagination as male, and that how we represent our political body or define community affects our notion of citizenship.

Moira Gatens, for example, suggests that the representation of the sovereign body as the product of man's reason, and as an artificial man created by men, reflects the wish for independence from women and nature. ${ }^{1}$ Gatens illustrates her argument through an examination of the stories which political theorists tell about the birth of Athena and the origins of Athens, the first true body politic. In classical mythology, Athena was not born of woman but of man: she sprang from the head of Zeus. ${ }^{19}$ Athens was named after Athena because she banished the feminine furies to the subterranean regions of Athens, thus confirming the masculinity of the political body. In the conventional story told by political theorists, Athens, like the Leviathan, is the product of man's reason, and has no mother. Thus, Gatens argues, the image of artificial man created by men reflects the masculinist wish to be free from the "necessary but difficult dealing with both women and nature”. ${ }^{20}$

In the stories told by political theorists, however, an important aspect of the classical story is often left out. Gatens reminds us that Athena does in fact have a mother of sorts. Zeus gave birth to Athena only after he had swallowed whole the body of his pregnant wife. ${ }^{21}$ Gatens uses the image of the pregnant woman inside the body of Zeus as a metaphor for the way that artificial man swallowed women whole and made us part of the sovereign body, "not by pact, not by covenant, but by incorporation". ${ }^{22}$ As a result, "the modern body politic has lived off its consumption of women's bodies”, ${ }^{23}$ without ever being seen to do so. Gatens 
argues that the traditional representation of the body politic as the product of masculine reason has two consequences domestically. First, women's bodies mark us as inappropriate analogues to the male political body. The sovereign body is represented as the fantasy of an impermeable, self-sufficient masculine body. Secondly, the image of a unified political body does not allow or accommodate difference easily. Using Gatens' metaphor of the pregnant wife in the belly of the body politic, as long as artificial man can maintain the apparent unity of the body politic through incorporation, he does not have to acknowledge difference nor acknowledge the contributions of women's bodies. Feminist challenges to the founding myths of sovereignty and citizenship thus provide an opportunity for rethinking the representativeness of the modern state, and the chance to imagine a body politic better able to represent collective identities and survivable political communities.

Feminist theorists have also considered the implications of the relationship between sovereignty, citizenship and political identity in a global context. The work of feminist international relations scholars and cultural theorists has broken down the barriers between foreign relations and domestic cultures, to show that external shows of state power are linked to internal cultural processes. ${ }^{24}$

In particular, feminists argue that the construction of masculinity and femininity plays a key role in the mobilisation of state power. From a feminist perspective, state power is not monolithic, but must constantly be produced and reproduced through complex appeals to citizenship, patriotism, economic interests and conceptions of gender. Only if such appeals are successful in controlling individual subjects can states "naturally" exercise their military and economic power in aggressive external or internal shows of force. ${ }^{25}$

\section{Citizens of the North ${ }^{26}$}

Northern feminists have begun to consider what it means to have citizenship in the North, in the context of a situation in which our security and well-being is built on the disciplining of super-exploited labour in the South, and on privileged access to resources and markets globally. As Jan Pettman argues, we need to locate political identities within structures of power which are increasingly global in nature and effect. ${ }^{27}$ Looking at the relationship between citizenship, sovereignty, imperialism and neoimperialism allows us to ask: how do we understand the nature of the political communities of which we are citizens in a global context? For what does the abstraction of sovereignty allow us to abrogate responsibility?

An important aspect of a feminist approach to citizenship is thus the need to research and teach about citizenship ethically, in the sense of drawing attention to the specificity of our embodiment, or of positioning ourselves somewhere. Feminist legal analyses of citizenship and sovereignty in the era of multinational capitalism must politicise/politicize and make visible the global networks of exploitation and oppression which are reinforced and made palatable through discourses of sovereignty, citizenship and security. ${ }^{28}$

\section{IMPLICATIONS FOR TEACHING ABOUT CITIZENSHIP}

Ideas about citizenship and sovereignty form the foundation of many subjects currently taught in Australian law schools, such as human rights, international law, constitutional law, and even contract and criminal law. The introduction of such material into a law or legal studies curriculum, however, inevitably makes necessary the evaluation of teaching methods. Questions of pedagogy become critical when teaching such material.

As many scholars have argued, exposure to feminist, postcolonial and critical theory for the first time can be an unsettling experience, both for students who take up the challenge to think critically about their self-constitution and the production of knowledge and reality, and for those who resist thinking about these things. In my teaching, I have found that asking students to think critically about issues of citizenship, sovereignty, North-South relations, imperialism and neoimperialism can turn the classroom into a dynamic place.

Reflecting on the responses of these students has led me to a number of conclusions about the ways in which the teaching of such material can usefully be approached. First, as bell hooks notes, nothing about my training really prepared me to witness students transforming themselves. ${ }^{29}$ It is, nevertheless, rewarding for me to witness students begin to think critically about knowledge, to develop new and more ethical 
responses to themselves and their situation in history, and to develop more engaged approaches to learning and education. Their enthusiasm, pleasure and courage at implementing such ideas challenges me to acknowledge, in hooks' words, "the power we have as teachers, as well as the awesome responsibility". ${ }^{30}$

There are also, of course, students who resist engaging with critical, feminist or postcolonial material. Margaret Thornton suggests the legal academy has resisted feminist legal scholarship because it necessarily challenges identities, work practices and relationships:

Law has been remarkably resistant to critical theory in the past, as illustrated by its unresponsiveness to movements such as Legal Realism, Critical Legal Scholarship, and Law and Economics. This resistance can be explained, to some extent, in terms of the generally atheoretical, positivistic and practice-oriented nature of Anglo-Australian legal education. The resistance towards feminist legal scholarship has a different character, however, not only because it is likely to have a human face within the academy, but because it is sustained by a feminist politics that confronts individual men of the academy in light of their practices as colleagues, husbands, lovers and fathers. ${ }^{31}$

Similarly, discussion and analysis of gender, race and class in a global context raises issues that are central to the ways in which students understand themselves and the world. It is, however, possible to harness the anger, hostility, fear or guilt felt by some students, to allow them to engage with critical or feminist material more actively.

One strategy is to acknowledge the difficult emotions that are aroused in discussions about class, gender, race and ethnicity. Students may be seeing themselves in ways they have never seen themselves before. For white middle-class men, for example, everything in the culture tells them they are invisible, that they speak and act from a neutral objective position, from nowhere. They are constructed as knowers, not as objects of knowledge. As a result, some find the realisation that women have produced sophisticated analyses of male identity disturbing. Similarly, for members of groups who may have understood themselves as oppressed, such as white middle-class women, it is again profoundly unsettling to find out that other groups of people position us as oppressors. I found it useful to raise those issues of position and power relations in the course of discussing relevant readings and addressing student responses to them. ${ }^{32}$

A second approach which becomes important when teaching such material is to try to find ways to communicate across the differences between members of the group. Communication is obviously much easier in a climate of respect, where students attempt to understand how others came to hold a particular position, and to consider what is at stake in rethinking that position as a result.

Finally, I feel optimistic about this kind of teaching. It generates excitement in the classroom. It is empowering for me and for my students to be able to take steps away from what is safe and known, away from people we share experiences and perspectives with, away from home, in order to be able to communicate across differences and boundaries that may seem insurmountable. So, in the spirit of possibility, I will leave the last word to bell hooks, who so eloquently describes the pleasures of "teaching to transgress": The classroom, with all its limitations, remains a location of possibility. In that field of possibility, we have the opportunity to labor for freedom, to demand of ourselves and our comrades, an openness of mind and heart that allows us to face reality even as we collectively imagine ways to move beyond boundaries, to transgress. This is education as the practice of freedom. ${ }^{33}$

$\dagger$ The ideas in this article were informed and inspired by discussions with Greta Bird, Hilary Charlesworth, Ian Duncanson, Judith Grbich, Adrian Howe, Andrea Rhodes-Little, Andrew Robertson and Margaret Thornton.

* Faculty of Law, The Australian National University.

(C) 1996. (1995) 6 Legal Educ Rev 251.

1 For analyses which develop this sense of “ethics”, see M Gatens, Corporeal Representation in/and the body politic, in R Diprose \& R Ferrell eds, Cartographies: Poststructuralism and the mapping of bodies and spaces (Sydney: Allen \& Unwin, 1991) 79; R Diprose, A "genethics" that makes sense, in Diprose \& Ferrell eds, supra, at 65; A Rhodes-Little, J Gillard \& S Cerepinko, In Search of the Ethics of Company Law (1994) 2 Austl Feminist LJ 180.

2 A Rhodes-Little, J Gillard \& S Cerepinko, supra note 1. The use of the doctrine of terra nullius to legitimise the dispossession of Aboriginal people and appropriation of their land is one example of the way in which international lawyers have been involved in the organisation of power relations between white and "other". For a discussion of that doctrine and its impact on the Aboriginal people of Australia, see H Reynolds, The Law of the Land (Victoria: Penguin, 1992). A critical analysis of the use of international law to dispossess colonised peoples can be found in A Anghie, "The Heart of My Home": Colonialism, Environmental Damage, and the Nauru Case (1993) 34 Harv Int'l LJ 445.

3 For examples of useful literature analysing the ways in which global economic restructuring is producing increased inequality at an alarming rate, see J Kelsey, Economic Fundamentalism (London: Pluto Press, 1995); J Stephens, Running Interference: An Interview with Gayatri Chakravorty Spivak, (1995) 7 (No 2) Austl Women's Book Rev 19; B Onimode, The IMF, the World Bank and African Debt: The Social and Political Impact (London: Zed Books and the Institute for African Alternatives, 1989); J Brecher \& T Costello, Global Village or Global Pillage: Economic Reconstruction From the Bottom Up (Boston: South End Press, 1994); C Raghavan, Recolonization: GATT and the Third World (London: Zed Books, 1991); S George \& F Sabelli, Faith and Credit: The 
World Bank’s Secular Empire (London: Penguin, 1994).

4 Rhodes-Little, Gillard \& Cerepinko, supra note 1, at 180.

5 See, for example, M Thornton, Portia Lost in the Groves of Academe Wondering What to do about Legal Education (1991) 9 Law in Context 12; I Duncanson, Broadening the Discipline of Law (1994) 19 Melb UL Rev 1075; I Duncanson, Legal Education and the Possibility of Critique (1993) 8 Can JL \& Soc 59; A Rhodes-Little, Teaching Lawyering Skills for the Real World: Whose Reality? Which World? Or, the Closing of the Australian Legal Mind (1991) 9 (No 2) Law in Context: Special Issue on Legal Education and Legal Knowledge 59.

6 See G C Spivak, Culture Alive (1995) 5 Austl Feminist LJ 3; G C Spivak, Outside in the Teaching Machine (New York: Routledge, 1993); b hooks, Yearning: Race, Gender and Cultural Politics (Boston: South End, 1990); EW Said, Representations of the Intellectual, (London: Vintage, 1994).

7 There is a growing body of feminist theory concerned with the problematic nature of the concepts of rights, democracy, citizenship and representation for women. See particularly M Thornton, The Liberal Promise (Melbourne: Oxford University Press, 1990); M Thornton, Embodying the Citizen, in M Thornton ed, Public \& Private: Feminist Legal Debates (Melbourne: Oxford University Press, 1995) 198; P Williams, The Alchem of Race and Rights (London: Virago Press, 1993); C Pateman, The Sexual Contract (Cambridge: Polity Press, 1988); I M Young, Justice and the Politics of Difference (Princeton: Princeton University Press, 1990); J Pettman, Living in the Margins: Racism, Sexism and Feminism in Australia (Sydney: Allen \& Unwin, 1992); C Mouffe, Feminism, Citizenship and Democratic Politics, in J Butler \& J W Scott eds, Feminists Theorize the Political (New York: Routledge, 1992) 369; A Yeatman, Postmodern Revisionings of the Political (New York: Routledge, 1994); A Orford, Liberty, Equality, Pornography: The Bodies of Women and Human Rights Discourse (1994) 3 Austl Feminist LJ 72.

8 See A Howe, The Constitutional Centenary: Absent Feminist Conversationalists (1995) 20 Melb UL Rev 218

9 See Pettman, supra note 7.

10 For a further development of that argument with respect to the gendered nature of citizenship, see Pateman, supra note 7; L Hunt, Eroticism and the Body Politic (Baltimore: The John Hopkins University Press, 1991); J Landes, Women and the Public Sphere in the Age of the French Revolution (Ithaca: Cornell University Press, 1988); Orford, supra note 7.

11 JUJU Pettman, Border Crossings: Minorities, Gender and the State in International Perspective, paper presented at a conference on The State in Transition, Melbourne, Australia, 6-8 August 1993, at 15.

12 Gatens, supra note 1, at 82; J B Elshtain, Sovereignty, Identity, Sacrifice, in V Spike Peterson ed, Gendered States: Feminist (Re)Visions of International Relations Theory (Boulder: Lynne Reinner Publishers, 1992) 141; G Lloyd, Selfhood, War and Masculinity, in C Pateman \& E Gross eds, Feminist Challenges: Social and Political Theory (Sydney: Allen \& Unwin, 1986 ) 63.

13 Williams, supra note 7 , at $164-65$.

14 RBJ Walker, From International Relations to World Politics, paper presented at a conference on The State in Transition: Reimagining the Local, National and International, La Trobe University, 6-8 August, 1993, at 7.

15 Id at 17.

16 Id at 2.

17 See particularly Thornton, Embodying the Citizen, supra note 7; Orford, supra note 7; Pateman, supra note 7; Mouffe, supra note 7; Pettman, supra note 7.

18 Gatens, supra note 1, at 80-81.

19 Id.

20 Ibid at 80.

21 Ibid at 81.

22 Id.

23 Id.

24 See, for example, V Spike Peterson, Security and Sovereign States: What Is at Stake in Taking Feminism Seriously, in Peterson ed, supra note 12, at 31; A Runyan, The State of Nature: A Garden Unfit for Women and Other Living Things, in Peterson ed, supra note 12, at 123; C Enloe, The Morning After: Sexual Politics at the End of the Cold War (Berkeley: University of California Press, 1993); A Tickner, Gender and International Relations (New York: Columbia University Press, 1992); Pettman, supra note 5; L Boose, Techno-Muscularity and the "Boy Eternal": From the Quagmire to the Gulf, in A Kaplan \& D E Pease eds, Cultures of United States Imperialism (Durham: Duke University Press, 1993); C Sylvester, Feminist Theory and International Relations in a Postmodern Era (Cambridge: Cambridge University Press, 1994).

25 For a further development of that argument, see A Orford, The Security Council: A Feminist Analysis, in Australian and New Zealand Society of International Law, Proceedings of Second Annual Meeting, 1994 (Canberra: Australian and New Zealand Society of International Law, 1994) 242.

26 I am using "North" here to refer to industrialised countries, and "South" to refer to non-industrialised countries. That terminology reflects the globalisation of international legal theory emanating from the US and Europe, a problem I do not have space to address here.

27 Pettman, supra note 11 , at 21

28 For an analysis of sovereignty based on that approach, see A Orford, The Dangerous Fiction of Collective Identity: Negotiating Sovereignty in a Postmodern Era, paper presented at the 17th International Society of the Philosophy of Law and Social Philosophy World Congress, Bologna, Italy, 16-21 June, 1995. Useful analyses of the destructive effects of global capitalism on the South can be found in G Spivak, Outside in the Teaching Machine (New York: Routledge, 1993), 1; Stephens, supra note 3; W Bello, Dark Victory: The United States, Structural Adjustment, and Global Poverty (London: Pluto Press, 1994); George \& Sabelli, supra note 3; Raghavan, supra note 3; P Stamp, Foucault and the New Imperial Order, (1994) 3 Arena Journal 11.

29 b hooks, Teaching to Transgress (New York: Routledge, 1994) 196.

30 Ibid at 206.

31 M Thornton, Discord in the Legal Academy: The Case of the Feminist Scholar (1994) 3 Austl Feminist LJ 53, at 54.

32 I am grateful to Judith Grbich for suggesting that strategy.

33 hooks, supra note 29, at 207. 